\title{
Physical and Mechanical Properties of Eco-Friendly Composites Made from Wood Dust and Recycled Polystyrene
}

\author{
Dafni Foti $^{1}$, Eleni E. Voulgaridou ${ }^{1}$, Sotirios Karastergiou ${ }^{2}$, Hamid R. Taghiyari ${ }^{3}$ and \\ Antonios N. Papadopoulos ${ }^{1, *}$
}

${ }^{1}$ Department of Forestry and Natural Environment, International Hellenic University, Drama, Greece

${ }^{2}$ Department of Forestry, Wood Sciences and Design, University of Thessaly, Karditsa, Greece

${ }^{3}$ Wood Science and Technology Department, Faculty of Materials Engineering \& New Technologies, Shahid Rajaee Teacher Training University, Tehran, Iran

*Corresponding Author: Antonios N. Papadopoulos. Email: antpap@for.ihu.gr

Received: 04 June 2021 Accepted: 15 June 2021

\begin{abstract}
The development of alternative wood composites based on the use of waste or recycled materials can be beneficial due to over exploitation of natural resources. Under this frame, an option for the successful utilization of waste polystyrene which avoids environmental problems that formaldehyde adhesives cause and also reduces waste disposal, is its potential application as a binder for the production of value-added environmentally friendly and low cost wood composites. Two types of panel were successfully made, consisting of wood dust and two recycled polystyrene contents, namely, $15 \%$ and $30 \%$. Both physical properties, water absorption and thickness swelling, and mechanical properties, modulus of rupture, shear strength parallel in the plane of the board and glue line shear strength, were significantly improved as the recycled polystyrene content increased from $15 \%$ to $30 \%$. Water absorption and thickness swelling after $24 \mathrm{~h}$ immersion in water were improved by $165 \%$ and $750 \%$ as the recycled polystyrene content increased from $15 \%$ to $30 \%$. The magnitude of the improvement in mechanical properties however, was less pronounced than of the physical properties since modulus of rupture, shear strength parallel in the plane of the board and glue line shear strength were increased by $43.6 \%, 50 \%$ and $61.5 \%$, respectively. The low viscosity of the recycled polystyrene caused more mobility inside the panel matrix and therefore, an improved penetration took place into adequate depth of the compressed dust particles. It is concluded that boards can be successfully produced using these waste raw materials, wood dust and recycled polystyrene in organic solvent as a binder, and therefore it can reduce waste disposal and provide cleaner production for the development of wood-based boards.
\end{abstract}

\section{KEYWORDS}

Cold pressing; composites; recycled polystyrene; wood dust

\section{Introduction}

The optimization of the efficiency of natural resources and the transition to circular economy has generated new actions to a more sustainable use of raw materials. Therefore, it is an imperative need the utilization and the concomitant conversion of waste materials into new high-value products. In particular,

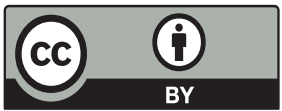

This work is licensed under a Creative Commons Attribution 4.0 International License, which permits unrestricted use, distribution, and reproduction in any medium, provided the original work is properly cited. 
the use of wood residues, or recycled materials can be considered as eco-friendly, green potentials in order to face the challenge of an increasing demand for wood composites, worldwide [1,2]. The definition of recycled wood, as stated in the Waste Framework Directive (2008/98/EC), includes a variety of residual and old wood, such as wastes from construction, furniture, etc., and packaging [3-5]. Both wood-based panel industries and pulp and paper facilities produce, annually, a substantial amount of by products, namely solid waste and nonhazardous sludge which require utilization as by-products or as waste materials $[6,7]$.

At the moment, the main actions for the disposal of the sludge, involves burning for energy reasons or landfilling. In addition, during the primary mechanical wastewater treatment, the majority of the suspended solids are removed and the resulted liquid sludge incorporates great quantities of residual wood fibers [8]; this will be considered as an important feedstock for the manufacture of wood composites, although are significant different in composition [9]. Various methods have been developed worldwide for reconstituting the waste from wood based panels, such as particleboard and medium density fiberboard, in order to solve the problem of recycling the wood composites [10]. These can be categorized as follows: chemically thermomechanical [11], hydrothermal [12,13], chemical [14] or mechanical [15,16]. However, these methods are considered to be quite difficult to be applied in practice, an exemption seems to be the mechanical processing when manufacturing particleboards [17]. A common problem is the hydrolytic way of obtaining wood particles from residual particleboards [10,17].

Various studies have been published concerning the effect of various types of recycled wood and other lignocellulosic wastes on the properties of wood composites. Czarnecki et al. [17], manufactured three layered particleboards bonded with urea formaldehyde resin (UF) and they replaced, $10 \%$ to $60 \%$ in the core layer, conventional wood chips with chips obtained from particleboards made from formaldehyde resins, namely urea and phenol formaldehyde (PF). They found that bending properties were lightly declined when $10 \%$ to $50 \%$ particles obtained from recycled PBs bonded with UF resin were used, whereas internal bond strength was significantly reduced when the portion of recycled particles in the PBs was only $10 \%$. It was further stated that boards made from particles obtained from recycled PBs bonded with PF resin showed by far the worst properties. This was attributed to the negative interaction of the new UF resin used with the original PF. The properties of particleboards manufactured from plywood waste (bonded with UF or PF resin) were investigated by Laskowska et al. [18]. They concluded that the substitution of $20 \%-100 \%$ of virgin particles with the recovered material was possible without negatively affecting the performance of the produced particleboard. Particleboards were also manufactured using four different types of wood recyclates, originated from demolished buildings, namely plywood, timber, particleboards and medium density fiberboards [19]. Particleboards made from recycled timber were shown the best performance, however the use of wood recyclated was recommended only for the core layer of the boards, since the bending properties were very low. Hameed et al. [20], made three layer particleboards from two types of recycled raw material, untreated wood and wood treated with various coatings. They reported that the produced boards met the requirements of no load-bearing panel for interior use in dry conditions. Iždinský et al. [21], made three layer particleboard bonded with UF resin, from fresh spruce wood, recycled wood chips and recycled faulty UF bonded particleboards, at various proportions. They reported that both mechanical and physical properties were negatively affected by the incorporation of the recycled material, whereas the boards made from $100 \%$ recycled material showed the worst performance.

Polystyrene is a synthetic, aromatic, thermoplastic polymer made from the monomer styrene. Styrene was first introduced to the market on industrial scale in early thirties by the German company IG Farben industries and by the Dow Chemical Company in USA; these employed the catalytic dehydrogenation of athylbenzene, a process that is still used nowadays [22]. Polystyrene is widely used for packaging applications and its Society for Plastic Industry code is 6, indicating the difficulty associated with its recycling. The common forms of polystyrene are general purpose polystyrene (GPPS), extruded 
polystyrene (XPS), expanded polystyrene (EPS), high impact polystyrene (HIPS) and syndiotatic polystyrene (SPS). Waste polystyrene has very serious environmental risks, particularly in developing countries, where disposal facilities are in shortage and its proper management is a big problem because it is not easy to recycle. It is known that despite the efforts being made by the industry to incorporate a small percentage in the manufacturing process, their management entails considerable costs of transportation, storage and disposal. Due to obvious lack of effective and appropriate strategies of its recycling, huge quantities of waste polystyrene are discarded in landfills, recycling plants or incinerated. Waste polystyrene is not decomposed in these facilities, getting dissolved by leaching of decomposition of another organic matter. Similarly, the gases resulting from the incineration of polystyrene are harmful [23]. Various researchers investigated the potential of using polystyrene as a binder in order to produce value-added wood composites. Masri et al. [24] successfully manufactured particleboards from expanded polystyrene (EPS) wastes and date palm and reported that the bending strength and stress reached acceptable values coupled with good fibre-matrix interface adhesion. Akinyemi et al. [25] made experimental particleboards from wastes of wood and expanded polystyrene foam. They concluded that wood and expanded polystyrene foam wastes can be considered as sustainable materials for producing panels that can be durable in moist environment. Hermawan et al. [26] manufactured oriented strand board bonded with disposal expanded polystyrene as binder. The results revealed that the mechanical properties met the Japansese standards, however thickness swelling remained a problem. Chanhoun et al. [27] examined the possibility of upgrading plastic waste, expanded polystyrene and wood, that pollute the environment of cities in Africa in general and those of Benin in particular. The study showed that, for the same polymer, the physicomechanical characteristics are different depending on the granular composition of the wood particles. It is further reported that the expanded polystyrene polymer provided high mechanical performance composites compared with those made with the plastic-based polymer. Polystyrene has been used for the manufacture of lightweight gypsum-based composites. Merino et al. [23] reported on the physicomechanical properties of lightweight gypsum-based composites made from various mixtures of polystyrene wastes, both expanded (EPS) and extruded (XPS). It was concluded that these type of composites complied with the current standards and had lower density than currently used lightweight gypsums and mechanical strengths. Expanded polystyrene has also been used for the manufacture of light weight concrete sandwich wall panels [28,29].

The above survey clearly showed that the development of alternative wood composites based on the use of waste or recycled materials can be beneficial due to over exploitation of natural resources. Under this frame, an option for the successful utilization of waste polystyrene, which at the same time, avoids environmental problems that formaldehyde adhesives cause and also reduces waste disposal, is its potential application as a binder, for the production of value-added, environmental friendly and low cost wood composites. In another connection, the approach of retraining polystyrene gotten from packing removed from service and wood or wastes of wood, permits the production of economic and environment respectful composites. Consequently, the aim of this paper was to examine the technical feasibility of manufacturing one layer particleboards made from wood dust and recycled polystyrene, as a binder.

\section{Materials and Methods}

\subsection{Raw Material}

Industrially produced wood wastes comprising of predominantly mixed softwoods were supplied by a local plant in Karditsa, Greece ( $39^{\circ} 22^{\prime} 21.7^{\prime \prime}$ N, $21^{\circ} 54^{\prime} 29.6^{\prime \prime}$ E). The wood chips were first screened through a mesh with $3 \mathrm{~mm}$ apertures to remove oversized particles, and they were then put through a mesh with $1.5 \mathrm{~mm}$ apertures to collect dust particles (Fig. 1). At least $89 \%$ of the dust particles were below $1 \mathrm{~mm}$ and $11 \%$ above $1 \mathrm{~mm}$, their bulk density was determined to be $0.30 \mathrm{~kg} / \mathrm{m}^{3}$. After screening, the dust particles were dried at $105^{\circ} \mathrm{C}$ to reach $6.5 \%-7 \%$ moisture content. The boards were manufactured from particles dried to this 
moisture content. Recycled polystyrene was collected from local landfills in Karditsa, Greece $\left(39^{\circ} 22^{\prime} 21.7^{\prime \prime}\right.$ $\mathrm{N}, 21^{\circ} 54^{\prime} 29.6^{\prime \prime} \mathrm{E}$ ) and chipped in a D.I.Y. shredder, as depicted in Fig. 2a. Following that, the polystyrene particles were mixed together in order a completely homogenous mass to be formed (Fig. 2b). Based on extensive preliminary results, it was found that a nitro-based solution of polystyrene, (type Nitro T-400, density $0.84 \pm 0.02 \mathrm{Kg} / \mathrm{L}$, purchased from Vitex, SA, Greece), $38 \%$ in concentration, resulted to the production of a fully homogeneous fine mass of polystyrene which was found to be suitable for spray application. This means that $100 \mathrm{~g}$ of polystyrene are dissolved in $266 \mathrm{ml}$ of the nitro-based solvent.

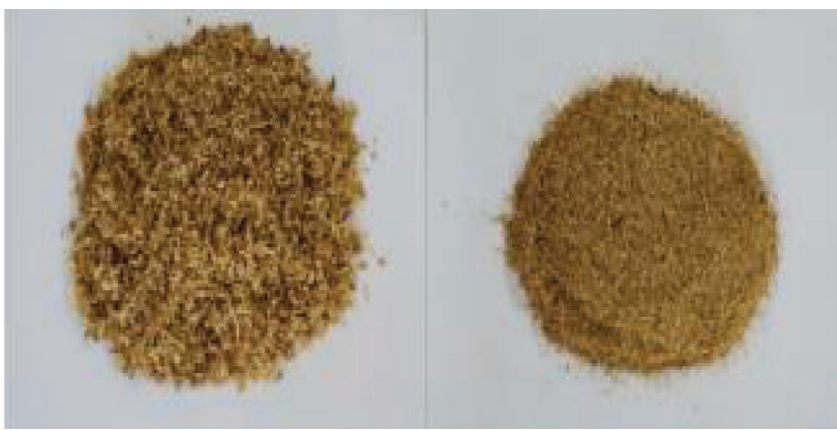

(a)

(b)

Figure 1: Wood wastes as collected (a) and as used (after screening) (b)

The determination of the viscosity of the recycled polystyrene was performed, at a temperature of $25.5^{\circ} \mathrm{C}$, using NDJ-1B rotational viscometer at a speed of $30 \mathrm{rpm}$.

\subsection{Board Manufacturing Process}

The dissolved polystyrene was sprayed on the wood dust in a rotary drum, while they were mixed together, before manually set in to $0.35 \mathrm{~m} \times 0.30 \mathrm{~m}$ matrix. The matrix was covered with metal plates, $3 \mathrm{~mm}$ in thickness, and tightens with hand clamps with a mechanical pressure of about $100 \mathrm{Kg}$ in order to be pre-pressed. The mats stayed under these conditions for $48 \mathrm{~h}$ at an average room temperature of $23^{\circ} \mathrm{C}$ before cold pressed for $6 \mathrm{~h}$, at $23^{\circ} \mathrm{C}$. The pressure of the cold press was $150 \mathrm{~kg} / \mathrm{m}^{2}$. The target board thickness was $12 \mathrm{~mm}$ and the target density was $0.65 \mathrm{~kg} / \mathrm{m}^{3}$. For each treatment, two replicates were produced. Two types of panel were made, consisting of two recycled polystyrene contents, namely, $15 \%$ (type A) and 30\% (type B) (based on the dry weight of wood dust) and wood dust. At this point, it has to be mentioned that preliminary tests revealed that it was not feasible to manufacture boards with lower polystyrene content, since this attempt leaded to non-consistent boards.

\subsection{Physicomechanical Properties of the Boards}

Once manufactured, the panels were conditioned at $23^{\circ} \mathrm{C}$ and $65 \%$ relative humidity. The values for mechanical properties, namely, hardness (Janka), modulus of rupture in bending strength (MOR), shear strength parallel in the plane of the board and glue line shear strength were determined according to the American standard for particleboards (ANSI A208.1-1998) [30]. Physical properties, namely, water absorption (WA) and thickness swelling (TS), were determined according to the European Union standards (EN 317-1993) [31]. For each oven-dried sample (four for each board), its weight and its dimensions were recorder and subsequently were immersed in water at $20^{\circ} \mathrm{C}$, for $24 \mathrm{~h}$. Both properties were calculated based of initial oven-dried recordings. The density profile of the samples was calculated at an interval of $0.1 \mathrm{~mm}$, using an ATR density profilometer (Industrie Elektronik), by means of gamma 
radiation, which is transmitted through the sample across its thickness. The flow diagram of the experimental procedure is depicted in Fig. 3.

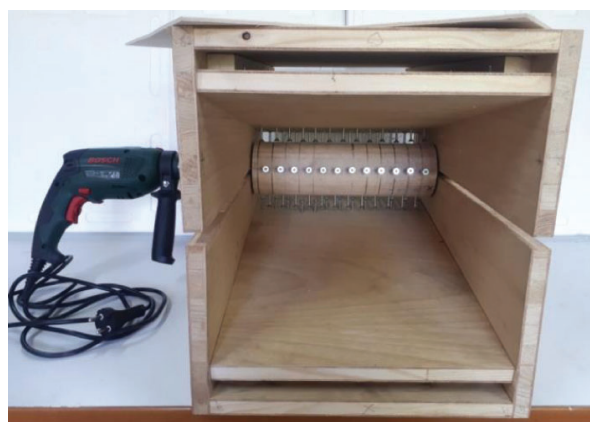

(a)

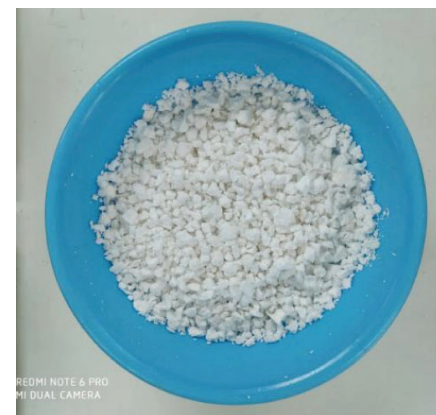

(b)

Figure 2: Completely homogeneous mass of recycled polystyrene (b) as produced by the shredder (a)
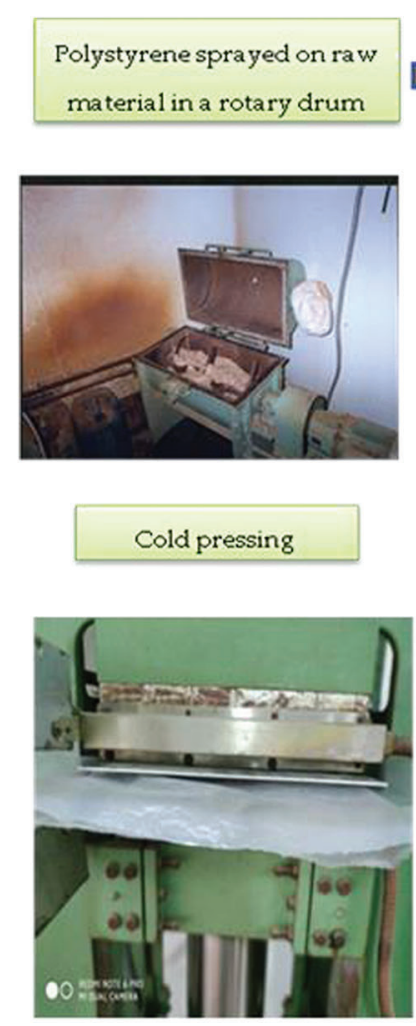
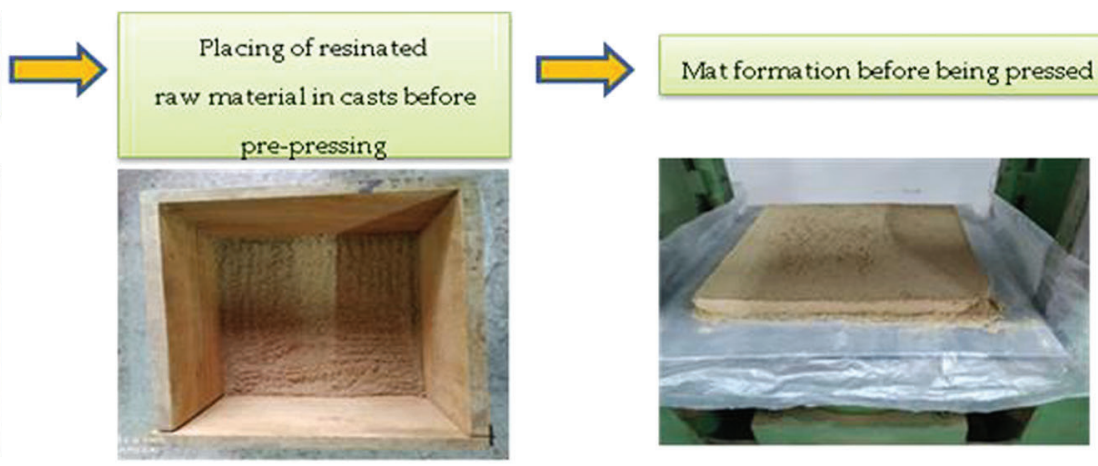

Mat formation before being pressed
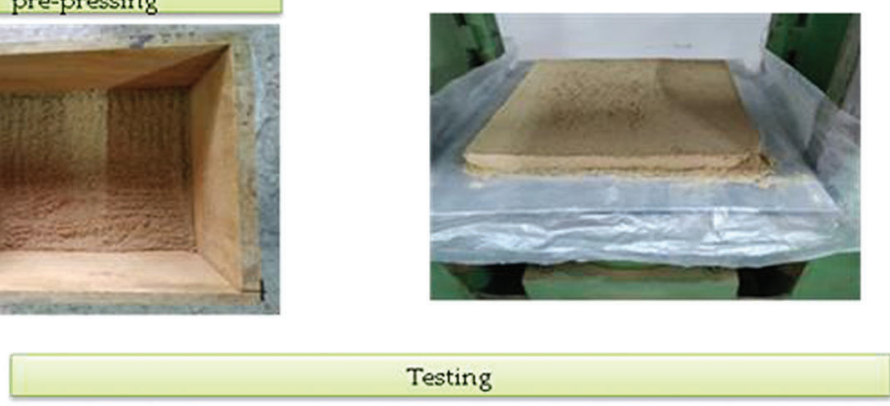

1.Mechanical Properties

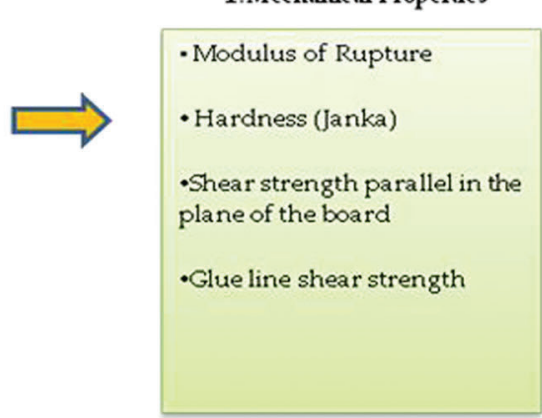

2.Physical Properties

-Water Absorption(2 \& 24h)

-Thickness Swelling ( 2 \& $24 \mathrm{~h})$

Figure 3: The flow diagram of the experimental procedure

\subsection{Statistical Analysis}

Statistical analysis was conducted using SPSS software program, version 24.0 (IBM, USA, 2018). Oneway ANOVA was performed to identify significant difference at the 95\% level of confidence, with Duncan's multiple range test grouping. Fitted-line, contour, and surface plots were designed using Minitab statistical software to discern relationship between properties and the trends thereof (version 16.2.2; 2010). 


\section{Results and Discussion}

\subsection{Properties of EPS}

The viscosity of the recycled polystyrene was $54.6 \mathrm{mPa}$ s at a temperature of $25.5^{\circ} \mathrm{C}$ and its $\mathrm{pH}$ value was 11.8. This denotes that EPS binder has a pretty low viscosity value compared to common formaldehyde based resins (200-400 $\mathrm{mPa} \mathrm{s}$ ) [32-33]. It is known that low viscosities-dispersion is advantageous since they are easier to distribute on the raw material and therefore can result in boards with improved properties [34]. This is particularly important for this study, since at least $89 \%$ of the dust particles, used in for the manufacture of boards, were below $1 \mathrm{~mm}$.

\subsection{Physical Properties}

The two types of panel made in this study, consisting of wood dust and two recycled polystyrene contents, namely, 15\% (type A) and 30\% (type B), as shown in Fig. 4.

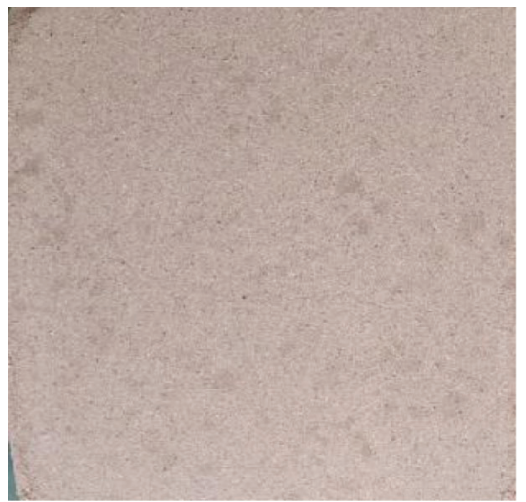

(a)

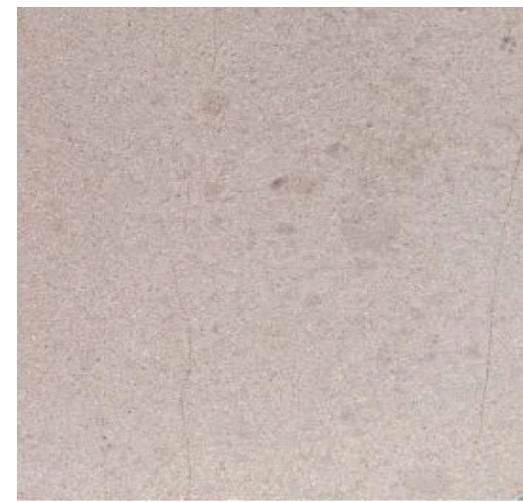

(b)

Figure 4: Appearance of the final boards made from wood dust and recycled polystyrene (a: $15 \%$ and $b$ : $30 \%)$

The physical properties of the particleboards made from wood dust and two recycled polystyrene contents are shown in Tab. 1. An increase in WA and TS was observed as the duration of immersion time increased. Closer inspection of the data depicted in Tab. 1, reveals that both water absorption and thickness swelling decreased as the recycled polystyrene content increased from $15 \%$ to $30 \%$; it is noticeable that this improvement in physical properties is significantly different. It is also of interest to notice the differences in the integrity of the two types of boards after $24 \mathrm{~h}$ immersion in water, as depicted in Fig. 5. Two factors may be responsible for this behavior. It is mentioned earlier that recycled polystyrene binder has a pretty low viscosity value compared to common formaldehyde based resins and this caused high mobility on contact with wood surface. As the content of the recycled polystyrene was increased from $15 \%$ to $30 \%$, more mobility took place inside the panel matrix and therefore an improved penetration lead to adequate depth of the compressed dust particles. This may cause a concomitant prevention or even repair of the potential damages of dust particles caused by cracks and fissures, since raw materials of fine sizes, like the ones used in this study, are relatively weak and vulnerable to 'critical defects' inside the board structure. This improvement in water absorption and thickness swelling as the content of the recycled polystyrene is increased, have also been reported by other researchers in boards made from commercially produced wood chips [35-37], however the magnitude of the improvement is more pronounced in the present study where dust particles were used as raw material, namely $165 \%$ and $750 \%$ in WA and TS after $24 \mathrm{~h}$ immersion in water, respectively. An additional factor that contributed to 
this significant improvement of the two physical properties studied here as the recycled polystyrene content increased, may be the better interfacial contact between dust-matrix bonding in recycled polystyrene. This resulted in the formation of covalent bonds between the recycled polystyrene and the hydroxyl groups of the dust particles, as schematically depicted in Fig. 6; the bonds contributed to the connection between the polymer in the recycled polystyrene and to dust particles and this in turn bridged the gap between the dust particles [38]. It is generally known that the strength of the bond is determined by the resin content $[39,40]$. While a hydrogen bond (through mechanical means) is formed when conventional formaldehyde resins are used, a covalent bond is formed when recycled polystyrene is applied as a binder. A value of energy range of 5-10 kcal/mol is linked with hydrogen bond, while a value of $70-100 \mathrm{kcal} / \mathrm{mol}$ with the covalent bond [39]. As a consequence, an increase in recycled polystyrene from $15 \%$ to $30 \%$ resulted in an increased strength of the covalent bond with corresponding increase in the energy range and this in turn resulted in significant improvement in both physical properties studied here.

Table 1: Physical properties of the two types of board made in this study

\begin{tabular}{|c|c|c|c|c|c|}
\hline \multirow[t]{2}{*}{ Board type } & \multirow[t]{2}{*}{$\begin{array}{l}\text { Density }^{1} \\
\left(\mathrm{Kg} / \mathrm{m}^{3}\right)\end{array}$} & \multicolumn{2}{|c|}{$\begin{array}{c}\text { Water absorption (WA })^{1} \\
(\%)\end{array}$} & \multicolumn{2}{|c|}{$\begin{array}{c}\text { Thickness swelling (TS) } \\
(\%)\end{array}$} \\
\hline & & $2 \mathrm{~h}$ & $24 \mathrm{~h}$ & $2 \mathrm{~h}$ & $24 \mathrm{~h}$ \\
\hline $\begin{array}{l}\text { Type A } \\
\text { (15\% recycled polystyrene) }\end{array}$ & $\begin{array}{l}0.67 \mathrm{~A}^{3} \\
( \pm 0.02)^{2}\end{array}$ & $\begin{array}{l}38.83 \mathrm{~A} \\
( \pm 3.74)\end{array}$ & $\begin{array}{l}125.44 \mathrm{~A} \\
( \pm 6.46)\end{array}$ & $\begin{array}{l}4.01 \mathrm{~A} \\
( \pm 1.68)\end{array}$ & $\begin{array}{l}34.84 \mathrm{~A} \\
( \pm 6.57)\end{array}$ \\
\hline $\begin{array}{l}\text { Type B } \\
\text { (30\% recycled polystyrene) }\end{array}$ & $\begin{array}{l}0.63 \mathrm{~A} \\
( \pm 0.01)\end{array}$ & $\begin{array}{l}7.92 \mathrm{~B} \\
( \pm 2.91)\end{array}$ & $\begin{array}{l}47.33 \mathrm{~B} \\
( \pm 5.09)\end{array}$ & $\begin{array}{l}0.68 \mathrm{~B} \\
( \pm 0.37)\end{array}$ & $\begin{array}{l}4.09 \mathrm{~B} \\
( \pm 1.21)\end{array}$ \\
\hline
\end{tabular}

Notes: ${ }^{1}$ Each value is the mean of ten replicates.

${ }^{2}$ Standard deviation.

${ }^{3}$ Values followed by the same letter do not differ significantly from each other by a Duncan's multiple range test $\left(\alpha^{\prime}=0.05\right)$.

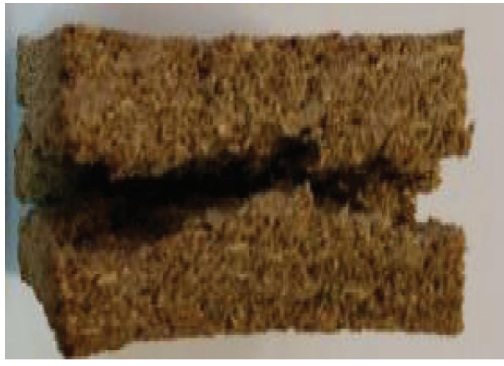

(a)

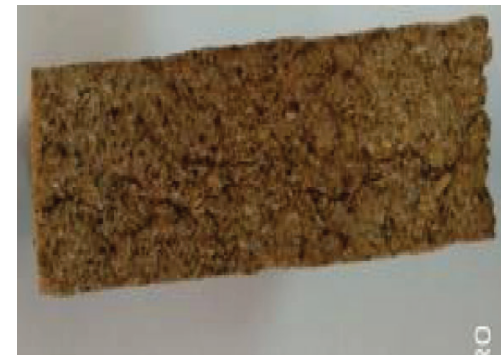

(b)

Figure 5: Appearance of samples after $24 \mathrm{~h}$ immersion in water (a) Type A board and (b) Type B board

\subsection{Mechanical Properties}

The mechanical properties of the particleboards made from wood dust and two recycled polystyrene contents are shown in Tab. 2. From this, it can be seen that an increase of the recycled polystyrene content from $15 \%$ to $30 \%$ resulted in significant improvement in the modulus of rupture, shear strength parallel in the plane of the board and glue line shear strength of the boards. The magnitude of the improvement however, was less pronounced than of the physical properties; i.e., modulus of rupture, shear strength parallel in the plane of the board and glue line shear strength were increased by $43.6 \%$, $50 \%$ and $61.5 \%$, respectively. This improvement is caused by the strong binding force and compaction strength at the interface between the dust particles and the recycled polystyrene. The ability of the 
recycled polystyrene to penetrate into the crevices and voids of the produced boards resulted to improved mechanical interlocking and improved efficacy of transferring of the resulted stress along the interfaces $[32,41,42]$.

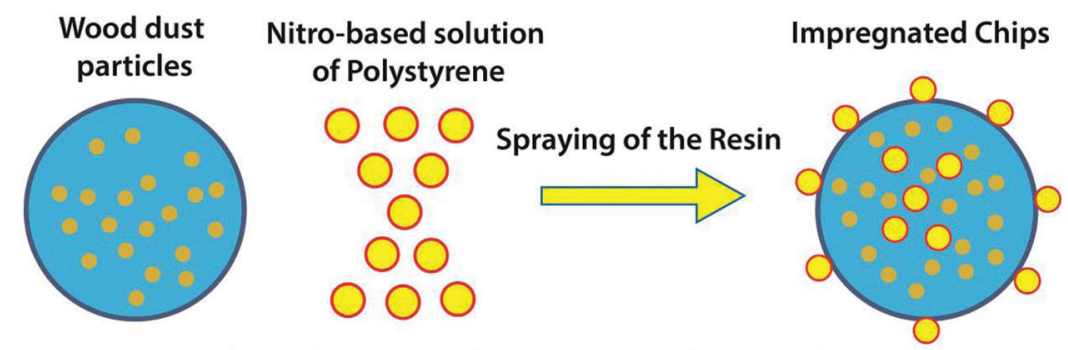

Scheme formation of covalent bond between the EPS and the hydroxyl groups of the dust particles

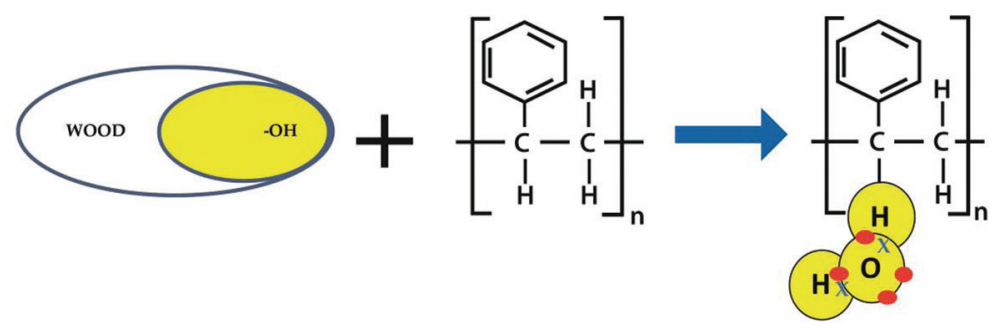

Figure 6: Schematic representation of the formation of covalent bond between the recycled polystyrene and the hydroxyl groups of the dust particles

Table 2: Mechanical properties of the two types of board made in this study

\begin{tabular}{llllll}
\hline Board type & $\begin{array}{l}\text { Density } \\
\left(\mathrm{Kg} / \mathrm{m}^{3}\right)\end{array}$ & $\begin{array}{l}\text { Modulus } \\
\text { of rupture } \\
(\mathrm{MOR})^{1} \\
\left(\mathrm{~N} / \mathrm{mm}^{2}\right)\end{array}$ & $\begin{array}{l}\text { Hardness } \\
\left(\mathrm{N} / \mathrm{mm}^{2}\right)\end{array}$ & $\begin{array}{l}\text { Shear strength } \\
(\text { parallel in the } \\
\text { plane of the board }) \\
\left(\mathrm{N} / \mathrm{mm}^{2}\right)\end{array}$ & $\begin{array}{l}\text { Glue line } \\
\text { shear } \\
\text { strength }^{1} \\
\left(\mathrm{~N} / \mathrm{mm}^{2}\right)\end{array}$ \\
\hline $\begin{array}{l}\text { Type A } \\
(15 \% \text { recycled }\end{array}$ & $\begin{array}{l}0.67 \mathrm{~A}^{3} \\
( \pm 0.02)^{2}\end{array}$ & $\begin{array}{l}1.65 \mathrm{~A} \\
( \pm 0.41)\end{array}$ & $\begin{array}{l}23.70 \mathrm{~A} \\
( \pm 1.21)\end{array}$ & $\begin{array}{l}0.36 \mathrm{~A} \\
( \pm 0.06)\end{array}$ & $\begin{array}{l}( \pm 0.65 \mathrm{~A} \\
( \pm 0.19)\end{array}$ \\
$\begin{array}{l}\text { Type B } \\
(30 \% \text { recycled polystyrene })\end{array}$ & $\begin{array}{l}0.63 \mathrm{~A} \\
( \pm 0.01)\end{array}$ & $\begin{array}{l}2.37 \mathrm{~B} \\
( \pm 0.65)\end{array}$ & $\begin{array}{l}14.50 \mathrm{~B} \\
( \pm 1.11)\end{array}$ & $\begin{array}{l}0.54 \mathrm{~B} \\
( \pm 0.07)\end{array}$ & $\begin{array}{l}1.05 \mathrm{~B} \\
( \pm 0.21)\end{array}$ \\
\hline
\end{tabular}

Notes: ${ }^{1}$ Each value is the mean of ten replicates.

${ }^{2}$ Standard deviation.

${ }^{3}$ Values followed by the same letter do not differ significantly from each other by a Duncan's multiple range test $\left(\alpha^{\prime}=0.05\right)$.

It is of interest to notice the behavior of the two types of boards produced in this study, as far as their hardness is concerned. Boards consisting of $30 \%$ recycled polystyrene showed by far lower value in hardness compared with those consisting of $15 \%$, the opposite of what it was expected since it is generally known that an increase in resin content increases the mechanical properties of boards [43-44]. It is further known that the amount of fillers or nanofillers which facilitate the curing of the resin cause an increase in mechanical performance of boards [45-47]. Considering the fact that the amount of recycled polystyrene used in type B panels was very high (30\%), the significant decrease in hardness was attributed to the increased 
compactness of the boards. This compactness, as a decisive factor, did not allow the completion of the test and therefore a preliminary low value in hardness was obtained.

During the pressing of the boards, the interaction between pressure and moisture gives rise to a non uniform deformation of the elements which in turn results in an uneven distribution of the density along the thickness direction of the final board. Typically, as stated by Kelly [48], the density profile resembles a 'U-shape' with the peak density near the board surfaces, and the lower in the core region. Fig. 7 shows typical profiles for the two types of board produced in this study. It is interesting to notice that boards made with $15 \%$ polystyrene, showed a steeper profile; that is higher surface densities and lower core densities than the boards made with $30 \%$ polystyrene. This suggests that boards made with $30 \%$ polystyrene were less compressible than the boards made with $15 \%$ polystyrene.

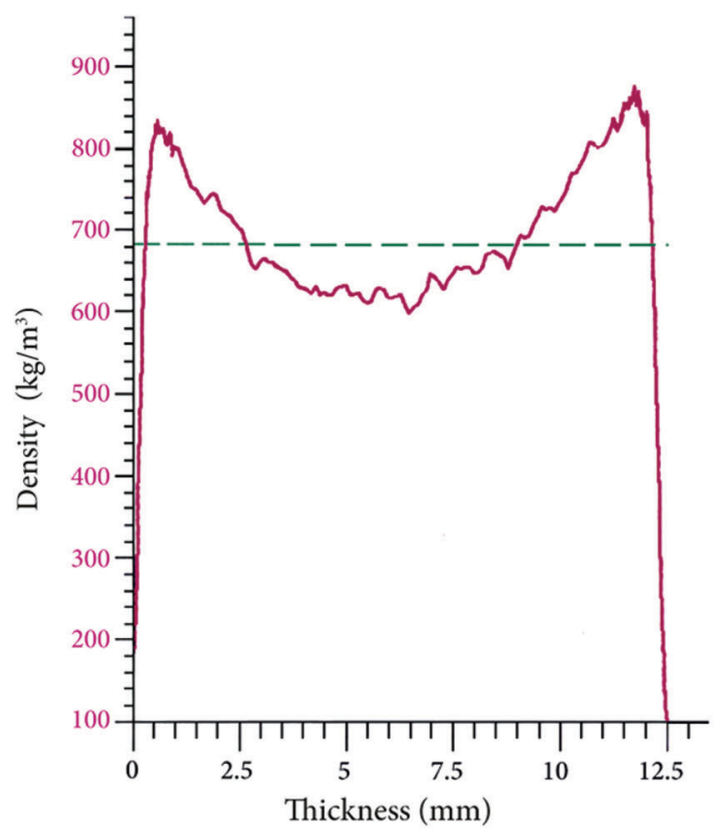

(a)

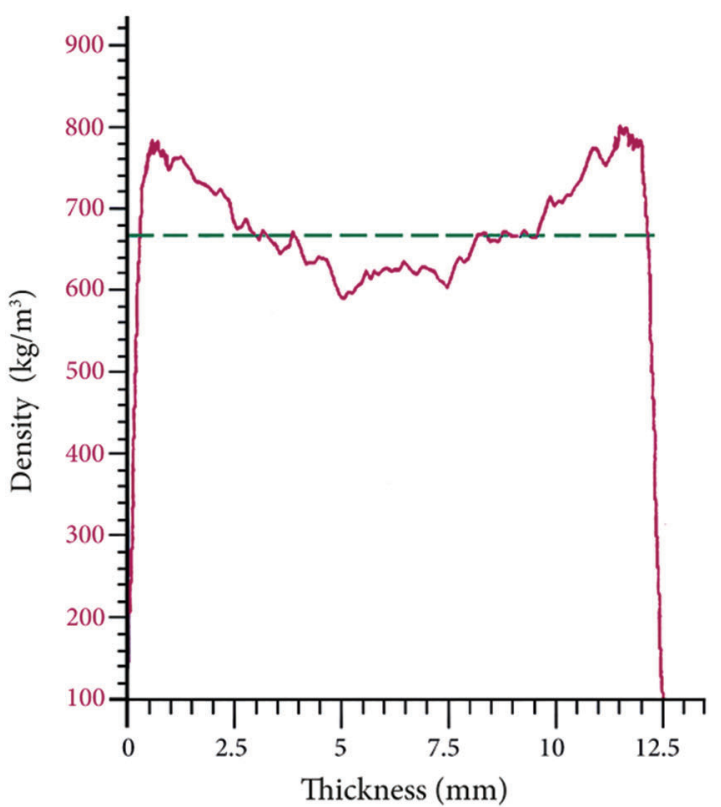

(b)

Figure 7: Density profiles of tested boards made from wood dust and recycled polystyrene (a: $15 \%$ and b: $30 \%$ )

Fitted-line plots between different physical and mechanical properties demonstrated rather high $\mathrm{R}$-squared values in most cases, though in some cases they were not statistically significant (Figs. 8A and 8B). Moreover, contour and surface plots illustrated clear relationship between most physical and mechanical properties, though some slight discrepancies were observed (Figs. 9A and 9B). The existence of relationship between different properties indicated that the properties studied here would be closely dependant on the content of the materials used and therefore, fluctuations could be made in them to manage quality of the boards produced at industrial scales. However, it is recommended that complementary studies with wider content range of recycled polystyrene be carried out, in case the industry decides to start up a production line.

A major issue addressed in this paper was to produce one layer particleboards made from wood dust and recycled polystyrene, as a binder. Two types of panel were successfully made, consisting of two recycled polystyrene contents, namely, 15\% (Type A) and 30\% (Type B) (based on the dry weight of wood dust). Their potential application can contribute in the reduction of cooling and heating costs and at the same time to eliminate $\mathrm{CO}_{2}$ emissions. The approach of retraining polystyrene gotten from packing removed from service and wood or wastes of wood, permits the production of economic and environment 
respectful composites. The limited energy demand for the construction of these board types is expected to improve the carbon footprint of the boards and also to address a financially viable solution for producers who currently direct the residues in landfills with an additional cost. It was mentioned in Section 2.1 that based on extensive preliminary results, it was found that a nitro-based solution of polystyrene, $38 \%$ in concentration, resulted to the production of a fully homogeneous fine mass of polystyrene which was found to be suitable for spray application. This may affect the emission of volatile organic compounds from the final board. This issue is of vital importance for the performance of the panel and will be reported in due course in a study that is currently under way and examines the potential of manufacturing composites made from wood particles and recycled polystyrene as a binder.

A

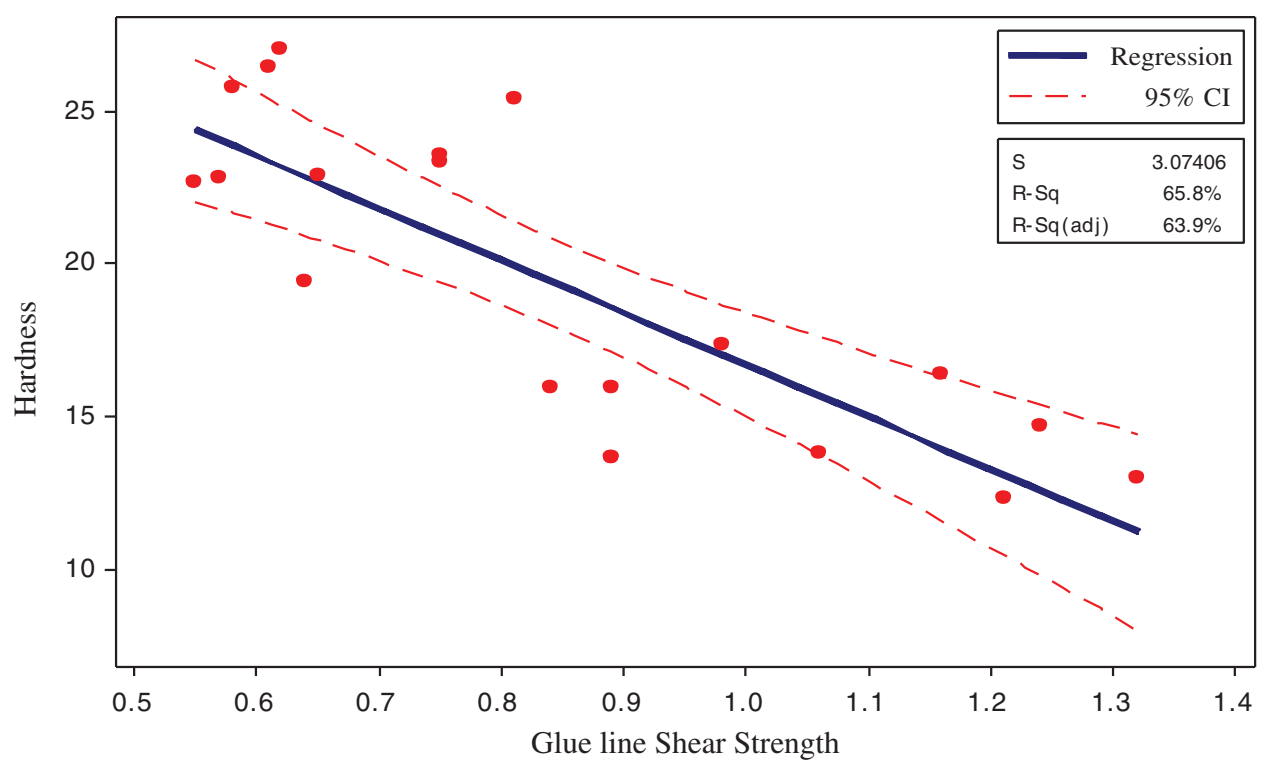

B

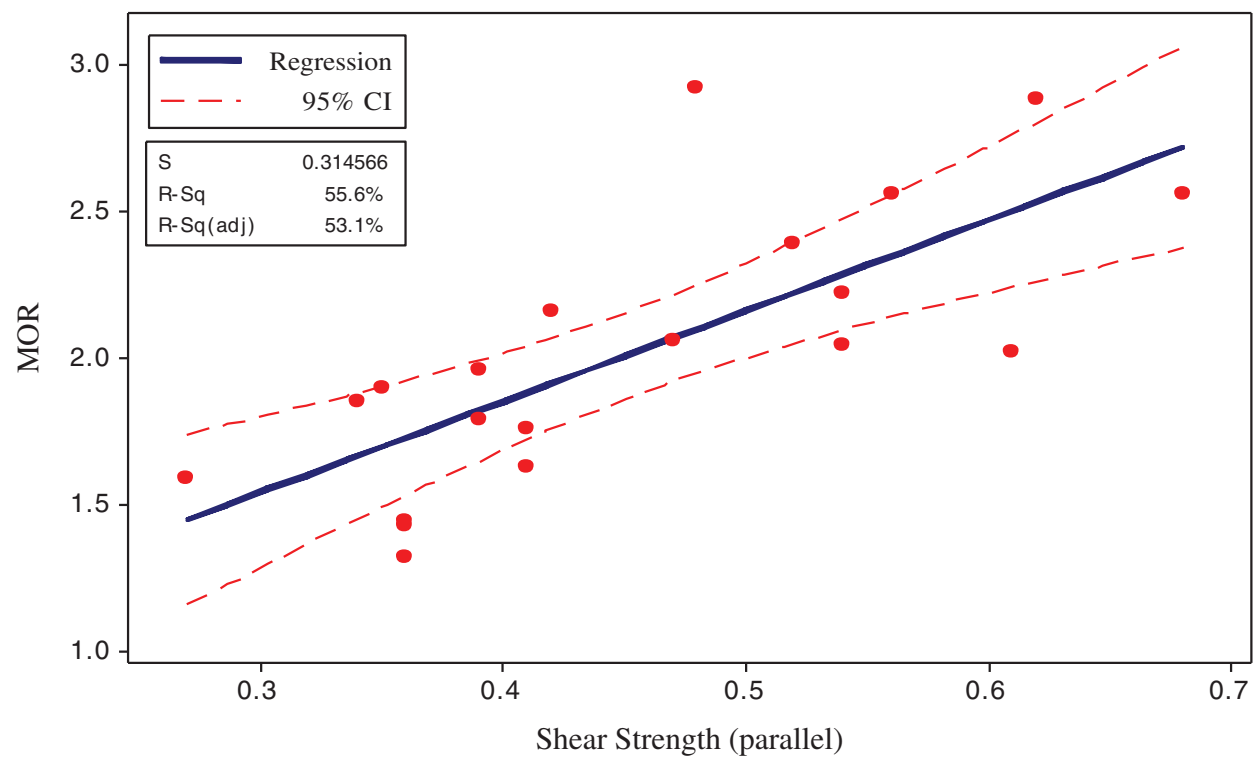

Figure 8: Fitted-line plots between hardness and glue line shear strength (A), and modulus of rupture (MOR) and shear strength parallel in the plane of the board (B) in particleboards made from different contents of wood dust and recycled polystyrene 


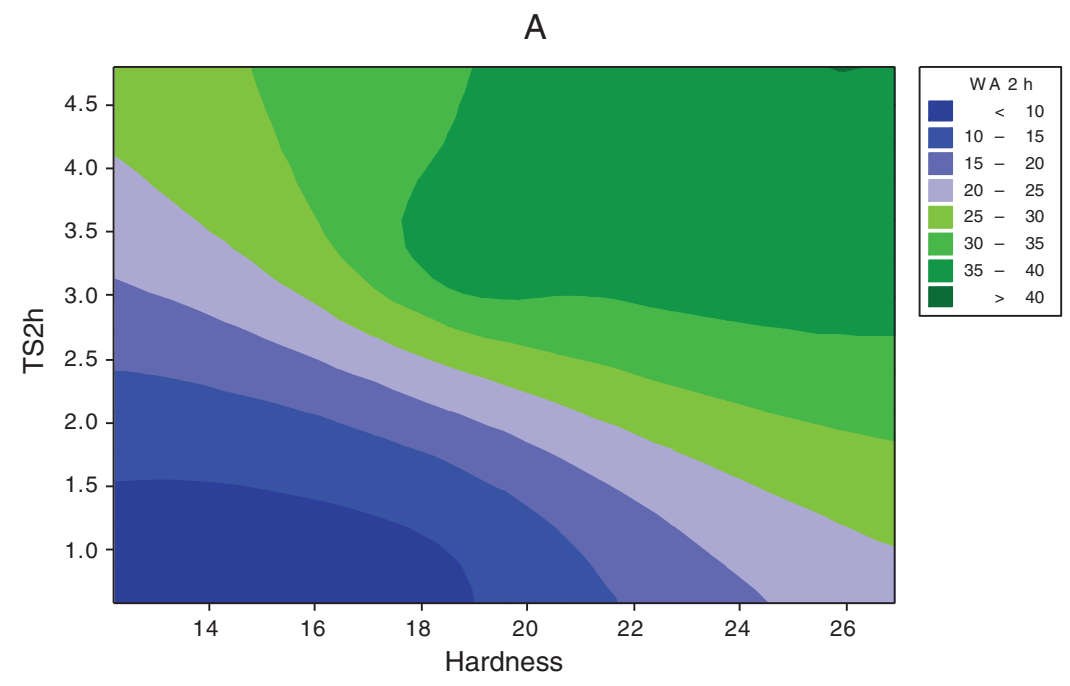

B

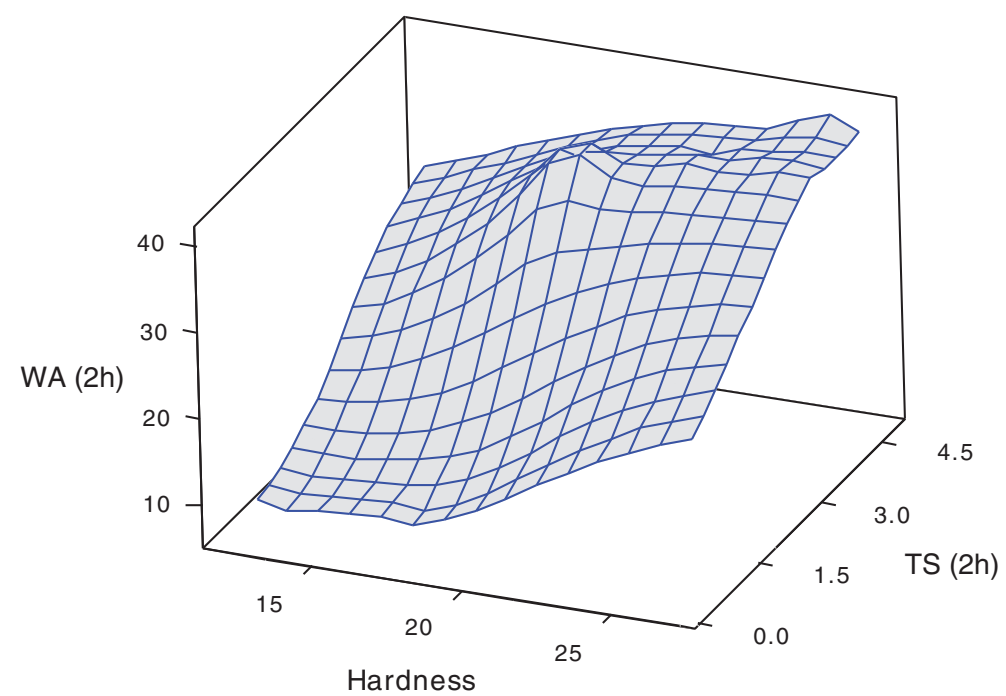

Figure 9: Contour (A) and surface (B) plots between physical and mechanical properties of particleboards made from different contents of wood dust and recycled polystyrene

\section{Conclusions}

The aim of this paper was to examine the technical feasibility of manufacturing one layer particleboards made from wood dust and recycled polystyrene, as a binder. At least $89 \%$ of the dust particles used was below $1 \mathrm{~mm}$. Two types of panel were successfully made, consisting of two expanded polystyrene contents, namely, $15 \%$ and $30 \%$. Both physical properties, water absorption and thickness swelling, and mechanical properties, modulus of rupture, shear strength parallel in the plane of the board and glue line shear strength, were significantly improved as the recycled polystyrene content increased from $15 \%$ to $30 \%$. The low viscosity recycled polystyrene caused more mobility inside the panel matrix and therefore an improved penetration took place into adequate depth of the compressed dust particles. Statistical analyses demonstrated relationship between most of the properties, upon which production planning can 
be established for the industry. It is concluded that boards can be successfully produced using these waste raw materials, namely wood dust and recycled polystyrene and therefore can reduce waste disposal and provide cleaner production for the development of eco-friendly wood-based boards.

Acknowledgement: We appreciate the kind efforts and valuable assistance of the Emeritus Professors, at the Department of Forestry and Natural Environment-Aristotle University of Greece, Dr. Elias Voulgaridis and Dr. Costas Passialis.

Funding Statement: This research is co-financed by Greece and the European Union (European Social Fund-ESF) through the Operational Programme 'Human Resources, Development, Education and Lifelong Learning 2014-2020' in the context of the project 'Innovative wood plastic composites made from recycled polystyrene and recycled wood chips' (MIS 5048422).

Conflicts of Interest: The authors declare that they have no conflicts of interest to report regarding the present study.

\section{References}

1. Antov, P., Mantanis, G. I., Savov, V. (2020). Development of wood composites from recycled fibres bonded with magnesium lignosulfonate. Forests, 11, 613. DOI 10.3390/f11060613.

2. Antov, P., Krišt'ák, L., Réh, R., Savov, V., Papadopoulos, A. N. (2021). Eco-friendly fiberboard panels from recycled fibers bonded with calcium lignosulfonate. Polymers, 13, 639. DOI 10.3390/polym13040639.

3. Deppe, H. J., Ernst, K. (2000). Taschenbuch der Spanplattentechnik, 4th ed., pp. 552. Chap 12: WPC-Boom trotz europaweiter Flaute bei Holzwerkstoffen. DRW: Leinfelden-Echterdingen, Germany.

4. The European Parliament and the Council (2008). Directive 2008/98/EC of the european parliament and the council of 19 November 2008 on waste and repealing certain directives. Official Journal European Union, 51, 3-30.

5. Gandhi, N., Farfaras, N., Wang, N. H. L., Chen, W. T. (2021). Life cycle assessment of recycling high-density polyethylene plastic waste. Journal of Renewable Materials, 9(8), 1463-1483. DOI 10.32604/jrm.2021.015529.

6. Sarazin, S., Pizzi, A., Amirou, S., Scchmiedl, D., Sernek, M. (2021). Organosolv lignin for non-isocyanate based polyurethanes (NIPU) as wood adhesive. Journal of Renewable Materials, 9(5), 881-907. DOI 10.32604/ jrm.2021.015047.

7. Tian, L., Qiu, L., Li, J., Yang, Y. (2020). Experimental study of waste tire rubber, wood-plastic particles and shale ceramsite on the performance of self-compacting concrete. Journal of Renewable Materials, 8(2), 154-170. DOI 10.32604/jrm.2020.08701.

8. Bajpai, P. (2015). Generation of waste in pulp and paper mills. Management of pulp and paper mill waste, Berlin/ Heidelberg, Germany: Springer.

9. Scott, G. M., Smith, A. (1995). Sludge characteristics and disposal alternatives for the pulp and paper industry. Proceedings of the International Environmental Conference, pp. 269-279. Atlanta, Georgia, Tappi Press.

10. Wan, H., Wang, X. M., Barry, A., Shen, J. (2014). Recycling wood composite panels: Characterizing recycled materials. BioResources, 9, 7554-7565. DOI 10.15376/biores.9.4.7554-7565.

11. Roffael, E., Dix, B., Behn, C., Bär, G. (2010). Use of UF-bonded recycling particle- and fibreboards in MDFproduction. European Journal of Wood and Wood Products, 68, 121-128. DOI 10.1007/s00107-009-0376-3.

12. Franke, R., Roffael, E. (1998). Zum recycling von span- und MDF-platten. Teil 1: Über die hydrolyseresistenz von ausgehärteten harnstoff-formaldehydharzen (UF-harzen) in span- und mitteldichten faserplatten (MDF). Holz als Roh-und Werkstoff, 56, 79-82. DOI 10.1007/s001070050268.

13. Lykidis, C., Grigoriou, A. (2008). Hydrothermal recycling of waste and performance of the recycled wooden particleboards. Waste Management, 28, 57-63. DOI 10.1016/j.wasman.2006.11.016. 
14. Michanickl, A. (1997). Recycling of laminated boards. Asian International Laminates Symposium, pp. 269-274. Hong Kong, China, Atlanta, Georgia, USA, TAPPI Press.

15. Ye, K., Yu, W., Qu, Y. (1998). Influence of water thermal treatment on particle form and recyclability of waste particleboard. China Wood Industries, 6, 7-9. DOI 10.1015/chinwoodind.1998.111374.

16. Roffael, E. (2002). Method for use of recycled lignocellulosic composite materials. U.S. Patent Application Publication US 2002/0153107 A1.

17. Czarnecki, R., Dziurka, D., Łecka, J. (2003). The use of recycled boards as the substitute for particles in the centre layer of particleboards. Electronic Journal of Polish Agricultural Universities, 6(2), 1. http://www.ejpau.media.pl/ volume6/issue2/wood/art-01.html.

18. Laskowska, A., Maminski, M. (2018). Properties of particleboard produced from post-industrial UF- and PFbonded plywood. European Journal of Wood and Wood Products, 76, 427-435. DOI 10.1007/s00107-0171266-8.

19. Azambuja, R. R., Castro, V. G., Trianoski, R., Iwakiri, S. (2018). Recycling wood waste from construction and demolition to produce particleboards. Maderas Ciencia y Technologia, 20, 681-690. DOI 10.4067/S0718$221 X 2018005041401$.

20. Hameed, M., Rönnols, E., Bramryd, T. (2019). Particleboard based on wood waste material bonded by leftover cakes of rape oil. Part 1: The mechanical and physical properties of particleboard. Holztechnologie, 6, 31-39.

21. Iždinský, J., Vidholdová, Z., Reinprecht, L. (2020). Particleboards from recycled wood. Forests, 11, 1166. DOI $10.3390 / \mathrm{f} 11111166$.

22. Chaukura, N., Gwenzi, W., Bunhu, T., Ruzixa, D., Pumure, I. (2016). Potential uses and value added products derived from waste polystyrene in developing countries: A review. Resources, Conservation and Recycling, 201(107), 157-165. DOI 10.1016/j.resconrec.2015.10.031.

23. Merino, M., Saez, P., Longobardi, I., Astorqui, J., Porras-amores, C. (2019). Redesigning lightweight gypsum with mixes of polystyrene waste from construction and demolition waste. Journal of Cleaner Production, 220, 144151. DOI 10.1016/j.jclepro.2019.02.132.

24. Masri, T., Ounis, H., Sedira, L., Kaci, A., Benchabane, A. (2018). Characterization of new composite material based on date palm leaflets and expanded polystyrene wastes. Construction and Building Materials, 164, 410418. DOI 10.1016/j.conbuildmat.2017.12.197.

25. Akinyemi, B. A., Okonkwo, C. E., Alhassan, E. A., Ajiboye, M. (2019). Durability and strength properties of particleboards from polystyrene wood wastes. Journal of Materials Cycles and Waste Management, 21, 15411549. DOI 10.1007/s10163-019-00905-6.

26. Hermawan, A., Ohuchi, T., Fyjimoto, N. (2010). Manufacture of strand board bonded with disposal expanded polystyrene as binder. Journal of Faulty of Agriculture Kyushu University, 2010(55), 107-110.

27. Chanhoun, M., Padonou, S., Adjovi, E. C., Olodo, E., Doko, V. (2018). Study of the implementation of waste wood, plastics and polystyrenes for various applications in the building industry. Construction and Building Materials, 167, 936-941. DOI 10.1016/j.conbuildmat.2018.02.080.

28. Fernando, P. L. N., Jayasinghe, M. T. R., Jayasinghe, C. (2017). Structural feasibility of expanded polystyrene (EPS) lightweight concrete sandwich wall panels. Construction and Building Materials, 2017, 45-51. DOI 10.1016/j.conbuildmat.2017.02.027.

29. Carvalho, C. H. R., Motta, L. A. C. (2019). Study about concrete with recycled expanded polystyrene. Revista Ibracon de Estruturas E Materials, 12, 1390-1407. DOI 10.1590/s1983-41952019000600010.

30. ANSI. Particleboard (1998). National Particleboard Association: Corvallis, OR, USA.

31. CEN (1993). Particleboards and fibreboards-determination of swelling in thickness after immersion in water; European Standard EN 317; CEN European Committee for Standardisation: Brussel, Belgium.

32. Pizzi, A., Papadopoulos, A., Policardi, F. (2020). Wood composites and their polymer binders. Polymers, 12, 1115. DOI 10.3390/polym12051115.

33. Pizzi, A. (2017). Urea and melamine amino resin adhesives. In: Pizzi, A., Mittal, K. L., (Eds.), Handbook of adhesive technology, 3rd ed., pp. 283-320. New York, NY, USA: Taylor and Francis. 
34. Gällstedt, M., Mattozzi, A., Johansson, E., Hedenqvist, M. S. (2004). Transport and tensile properties of compression-molded wheat gluten films. Biomacromolecules, 5, 2020-2028. DOI 10.1021/bm040044q.

35. Chaharmahali, M., Mirbagheri, J., Tajvidi, M., Najafi, S. K., Mirbagheri, Y. (2010). Mechanical and physical properties of wood-plastic composite panels. Journal of Reinforced Plastic and Composites, 29, 310-319. DOI 10.1177/0731684408093877.

36. Iulianelli, G., Tavares, M. B., Luetkmeyer, L. (2010). Water absorption behaviour and impact strength of PVC/ wood flour composites. Chemistry and Chemical Technology, 4, 1-5. DOI 10.23939/CHCHT04.03.225.

37. Kord, B. (2011). Effect of wood flour content on the hardness and water uptake of thermoplastic polymer composites. World Applied Sciences Journal, 12, 1632-1634.

38. Saad, M. J., Kamal, I. (2012). Mechanical and physical properties of low density kenaf core particleboards bonded with different resins. Journal of Science and Technology, 4, 1-16. https://publisher.uthm.edu.my/ojs/index.php/ JST/article/view/464.

39. Kumar, R. N., Pizzi, A. (2019). Environmental aspects of adhesives-emission of formaldehyde. Adhesives for wood and lignocellulosic materials, pp. 293-312. Hoboken, NJ, USA: Wiley-Scrivener Publishing.

40. Kumar, R. N., Pizzi, A. (2019). Urea-Formaldehyde resins. Adhesives for wood and lignocellulosic materials, pp. 61-100. Hoboken, NJ, USA: Wiley-Scrivener Publishing.

41. Papadopoulou, E. (2009). Adhesives from renewable resources for binding wood-based panels. Journal of Environmental Protection and Ecology, 10, 1128-1136.

42. Mamza, P. A., Ezeh, E. C., Gimba, E. C., Arthur, D. E. (2014). Comparative study of phenol formaldehyde and urea formaldehyde particleboards from wood waste for sustainable environment. International Journal of Scientific and Technological Research, 3, 53-61.

43. Dinwoodie, J. M. (1981). Timber: Its nature and behavior. Wokingham, Berks, UK: Van Nostrand Reinhold Company, Ltd.

44. Walker, J. C. F., Butterfield, B. G., Langrish, T. A. G., Harris, J. M., Uprichard, J. M. (1993). Primary wood processing: principles and practise. London, UK: Chapman \& Hall, Ltd.

45. Kumar, V. V., Balaganesan, G., Lee, J. K. Y., Esmaeely Neisiany, R., Surendran, S. et al. (2020). A review of recent advances in nanoengineered polymer composites. Polymers, 11, 644. DOI 10.3390/polym11040644.

46. Velmurugan, R., Balaganesan, G., Gupta, N. (2013). Impact loading on glass/epoxy composite laminates with nano clay. Key Engineering Materials, 535-536, 72-75. DOI 10.4028/www.scientific.net/KEM.535-536.72.

47. Taghiyari, H. R., Soltani, A., Esmailpour, A., Hassani, V., Gholipour, H. et al. (2020). Improving thermal conductivity coefficient in oriented strand lumber (OSL) using sepiolite. Nanomaterials, 10, 599. DOI 10.3390/ nano10040599.

48. Kelly, M. W. (1977). Critical literature review of relationships between processing parameters and physical properties of particleboard. USDA forest service general technical report FPL-10. Forest Products Laboratory, Madison, USA. 